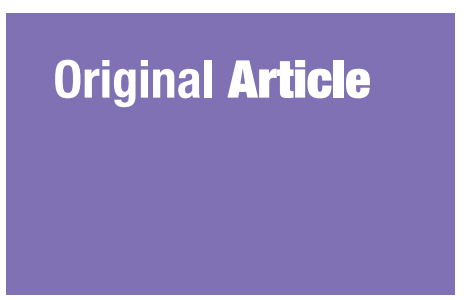

\title{
Knowledge, Awareness, Attitude and Preventive Behaviour on the Transmission of the Pandemic Novel Coronavirus Among Malaysians
}

Submitted: 3 Jun 2020

Accepted: 7 Dec 2020

Online: 21 Apr 2021

\author{
Norsa'AdAH Bachok ${ }^{1}$, Anis Kausar GhazalI ${ }^{1}$, Rohayu HamI ${ }^{2}$ \\ 1 Unit of Biostatistics and Research Methodology, School of Medical Sciences, \\ Universiti Sains Malaysia, Kubang Kerian, Kelantan, Malaysia \\ 2 Advanced Medical and Dental Institute, Universiti Sains Malaysia, Kepala \\ Batas, Pulau Pinang, Malaysia
}

To cite this article: Norsa'adah B, Ghazali AK, Hami R. Knowledge, awareness, attitude and preventive behaviour on the transmission of the pandemic novel coronavirus among Malaysians. Malays J Med Sci. 2021;28(2):106-118. https://doi.org/10.21315/mjms2021.28.2.10

To link to this article: https://doi.org/10.21315/mjms2021.28.2.10

\section{Abstract}

Background: Restricted movement and preventive actions have been introduced to break the chain of transmission of a new coronavirus. This study was conducted to determine the level of knowledge, awareness, attitude and preventive behaviour regarding the transmission of the COVID-19.

Methods: A cross-sectional study was conducted among Malaysians aged 20 years old and over, who had accessed the internet and used the WhatsApp application. The sampling method was a convenient snowball from 14 Malaysian states. This study was conducted online using questionnaires during the Movement Control Order due to the pandemic.

Results: Approximately 40.0\%, 46.1\% and 47.4\% of 1,290 participants had a score above the median (good score) for preventive behaviour, attitude and knowledge, respectively. Age was significantly associated with poor knowledge (adjusted odds ratio [AOR] 0.98; 95\% confidence interval [CI]: $0.97,0.99 ; P=0.026$ ). Males (AOR 1.35; 95\% CI: 1.05, 1.74; $P=0.021$ ), Malays (AOR 1.41; 95\% CI: 1.01, 1.98; $P=0.043$ ) and Chinese (AOR 2.19; 95\% CI: $1.17,4.13 ; P=0.015$ ) were the associated factors for poor attitude. Chinese ethnicity was significantly associated with poor preventive behaviour (AOR 2.80; 95\% CI: 1.39, 5.61; $P=0.004$ ).

Conclusion: The level of knowledge, attitude and practices were high except for a few questions. The young, males and Malay and Chinese individuals need health education.

Keywords: COVID-19, coronavirus, infection control, pandemic

\section{Introduction}

A novel coronavirus was first reported in December 2019 in Wuhan, China (1). The highly transmissible virus is called severe acute respiratory syndrome coronavirus 2 (SARSCoV-2) $(1,2)$, which causes coronavirus diseases, and was later known as COVID-19; this virus can cause a number of illnesses ranging from mild flu-like symptoms to life-threatening pneumonia (2).

The virus spread to Malaysia when a group of seven Chinese arrived in Malaysia via Singapore in January 2020. The situation worsened when a series of clusters occurred, with the major cluster being the Seri Petaling Tabligh cluster. The cluster is linked to a religious gathering held on 27 February to 1 March 2020, with more than 10,000 participants from Southeast Asia. This was the largest cluster to date, with a total of 1,701 positive cases that accounted for $48 \%$ of all positive cases in Malaysia (3).

The virus has spread worldwide, becoming a pandemic, as declared by the World Health Organization on 11 March 2020 (4). To date, 
there have been more than 109 million confirmed cases worldwide with 2.41 million deaths. The number of confirmed cases worldwide has reached immeasurable levels, forcing the affected countries to be in a lockdown state, including Malaysia. It is a necessary intervention to stop or slow down the transmission of COVID-19 while minimising the economic, public and social impacts. On 16 February 2021, there were 266,445 confirmed cases in Malaysia, with 975 deaths (0.37\%) (5).

Coronavirus is a new virus, the natural history of which is also new to most people. It is important to establish the level of knowledge of attitude towards and compliance with COVID-19 preventive actions. Raising public awareness of the transmission of COVID-19 and its symptoms will result in an increase in health-seeking behaviours as well as self-quarantine and the prevention of contacts. This study will help policy makers to identify the extent of Malaysians' awareness on this new disease, and how well we are complying and accepting new regulations to prevent this pandemic. Therefore, this study was conducted to determine the level of knowledge, awareness, attitudes and preventive behaviours regarding the transmission of the new pandemic COVID-19 among Malaysians.

\section{Methods}

The research design is a cross-sectional study. The study was conducted from April to May 2020. The source of population was those who have access to the internet and use the WhatsApp application. We included Malaysians aged 20 years old and over living in Malaysia and excluded those who were infected with COVID-19.

The sampling method was a convenient snowball sampling. Initially, we posted the survey invitation with the link to the Google Form via the WhatsApp application. The starting point was researchers' contacts, such as relatives and friends. In the post, we asked each of the individuals who received the link to pass it on to all of their adult friends and relatives. Then, the link was spread to others' contacts. We sampled the participants according to their state of residence. We included all Malaysians from 14 Malaysian states. Selangor state was the most populous state (5.46 million), followed by Johor (3.35 million) and Sabah (3.21 million) (6). Thus, participants from Selangor were sampled more than less populous states such as Perlis.
This study was conducted online during the Movement Control Order due to the pandemic.

A new set of questionnaires was designed to record all of the information, based on the literature (7) and previous research of the $\mathrm{H} 1 \mathrm{~N} 1$ influenza epidemic in 2010, which had been validated (8). The newly developed questionnaires were closed-ended with predetermined responses that consist of:

i) Sociodemographic characteristics such as age, sex, race etc.

ii) Seventeen questions on awareness and knowledge. The responses were 'yes' or 'no', and a score of 1 was given for the yes and $o$ for no. The maximum score was 17 and we converted the scores into percentages.

iii) Eight questions on attitude regarding their susceptibility and intention to comply. The responses have 4 point Likert rating: 'strongly agree', 'agree', 'disagree' and 'strongly disagree'. We gave score of 4 for strongly agree, 3 for agree, 2 for disagree and 1 for strongly disagree.

iv) Ten questions on level of compliance with prevention behaviour to stop the transmission of COVID-19. The responses have three ratings: 'all the time', 'sometimes' and 'not at all'. We gave a score of 2 for 'all the time', 1 for sometimes and 0 for 'not at all'.

These questionnaires were validated before use. The newly developed questionnaires were transformed into a Google Form. In the Google Form, voluntary participants had to sign in, which was limited themselves to only one attempt. Once respondents submitted the responses, they could not be edited or resubmitted. The Google Form was inaccessible after we received the required number of samples.

Household income was categorised according to the median economic group drawn by the Malaysian Department of Statistics (9). The poorest 40\% (B40) of households in Malaysia had a median income of $\mathrm{RM}_{3}, 000$, the middle 40\% (M40) had a median income of RM6,275 and the richest 20\% (T20) had a median income of RM13,148 (9).

\section{Statistical Analysis}

After reaching a sufficient number of respondents, data from the Microsoft Excel application were retrieved and transferred 
to the SPSS software version 25. Descriptive statistics were drawn to summarise all of the data. Numerical data were presented as mean (SD) or median (inter quartile range [IQR]) according to their distribution of normality and categorical data were presented as frequencies (percentages).

The dependent variables were knowledge, attitude and preventive behaviour towards COVID-19 infection. The scores of responses were totalled and then categorised by the median score into two categories: good and poor level. The poor level was coded as ' 1 ' and good level as ' $O$ ' in the data entry for SPSS. We first performed simple logistic regression, followed by multiple logistic regression for multivariable analysis to examine the association between sociodemographic characteristics and knowledge, attitude and behaviour. All variables that have $P$-values $<0.25$ in the simple logistic regression were included in the building of the preliminary model. The forward likelihood ratio (LR) and backward LR methods were used for model selection. We had chosen the simplest and most parsimonious fit model. The assumptions were checked for linearity of the continuous independent variable, multi-collinearity, interaction and fitness of the final model. Results of the model were presented with adjusted odds ratio (AOR), a 95\% CI and its corresponding $P$-value.

\section{Results}

We included 1,290 participants in the final analysis. Table 1 shows that the mean age of participants was 42.2 years (SD 10.2) with 74.1\% females. The majority were of Malay ethnicity, married with a degree education, working in the government sector and in the high-income group of T20. Only $7.1 \%$ had relatives or acquaintances who had tested positive for COVID-19.

Table 1. Sociodemographic characteristics of participants $(n=1,290)$

\begin{tabular}{lcc} 
Variables & Frequency (\%) & Mean (SD) \\
Age (years) & \\
Sex & $334(25.9)$ \\
Male & $956(74.1)$ \\
Female & \\
Ethnicity & $1,053(81.6)$ \\
Malay & $56(4.3)$ \\
Chinese & $20(1.6)$ \\
Indian & $161(12.5)$ \\
Others & \\
Marital status & $214(16.6)$ \\
Single & $1,013(78.5)$ \\
Married & $63(4.9)$ \\
Divorced/widow & $18(1.4)$ \\
Education Level & $146(11.3)$ \\
Primary school and less & $227(17.6)$ \\
High school & $706(54.7)$ \\
Diploma & $193(15.0)$ \\
Bachelor & \\
Master/PhD & \\
\hline & \\
\hline
\end{tabular}


Original Article | Awareness, attitude and behaviour on COVID-19 transmission

Table 1. (continued)

\begin{tabular}{lcc} 
Variables & Frequency (\%) & Mean (SD) \\
Occupation & $823(63.8)$ & $172(13.3)$ \\
Government sector & $99(7.7)$ & $69(5.3)$ \\
Private sector & $61(4.7)$ & $6,000(6,200)^{*}$ \\
Self-employed/odd job/others & $66(5.1)$ & \\
Housewife & & \\
Student & $626(48.5)$ & \\
Retired/un-employed & $385(29.8)$ \\
Family income (RM) & $279(21.6)$ & \\
T20 & $92(7.1)$ & \\
M40 & \\
B40 & \\
\hline
\end{tabular}

Note: * median (IQR)

Table 2 presents the responses to the questions on knowledge and awareness of COVID-19. Regarding the portal entry of coronavirus, $97.2 \%$ of the participants answered nose, $94.7 \%$ mouth and $77.0 \%$ eyes. Regarding the mode of transmission of the virus, more than 90\% answered 'yes' for all of the statements except for the eating wild animals. Only 58.7\% agreed that the coronavirus is transmissible through the consumption of wild animals. Most participants agreed that asymptomatic patients can transmit the virus, isolation can prevent transmission and quarantine should be implemented for 14 days for exposed individuals. Regarding the symptoms of COVID-19, most participants agreed that the symptoms were fever, cough and difficulty breathing. Only 57.3\% and $60.1 \%$ agreed on the symptoms of lethargy and runny nose, respectively.

Table 3 shows the responses for attitude statements. Statements 1 and 2 were about the vulnerability of people to infection, more than half of who disagreed. The other statements asked about their attitudes towards preventive measures; most of them had positive attitudes.

Compliance with most preventive behaviours, such as staying at home and avoiding crowded places, were respected all of the time. Avoid touching the face and covering the mouth when sneezing or coughing with a tissue or handkerchief were only sometimes complied with. These were shown in Table 4. Table 5 presents a summary of the descriptive results of the questions regarding knowledge, attitudes and practices. When we categorised the scores using the median as cut off point, 40.0\%, 46.1\% and $47.4 \%$ of participants had a score above the median (good score), for preventive behaviour, attitude and knowledge, respectively.

Table 2. Knowledge and awareness about COVID-19 of participants $(n=1,290)$

Portal of entry of coronavirus:

\begin{tabular}{lc} 
Eyes & $993(77.0)$ \\
Nose & $1,254(97.2)$ \\
Mouth & $1,222(94.7)$ \\
\hline & (continued on next page)
\end{tabular}


Table 2. (continued)

Mode of transmission of coronavirus:

Unconsciously touching the eye, nose or mouth with a contaminated hand

$1,263(97.9)$

Exposure to a respiration aerosol from a COVID-19 patient when talking, sneezing or coughing

$1,254(97.2)$

Staying close, less than a metre from a COVID-19 patient

$1,166(90.4)$

Touching any surfaces or doorknobs that are contaminated by a COVID-19 patient

$1,194(92.6)$

Shaking hands with a COVID-19 patient

$1,208(93.6)$

Eating wild animals such as bats

COVID-19 patients can spread disease even though they are healthy and show no symptoms

$1,246(96.6)$

Symptoms of COVID-19:

Fever

$1,222(94.7)$

Coughs

$1,242(96.3)$

Runny nose

$775(60.1)$

Breathing difficulties

$1,271(98.5)$

Lethargy

Isolation (quarantine) of COVID-19 patient can prevent the transmission of pandemic

Table 3. Attitude on susceptibility and intention to comply to prevent the transmission of COVID-19 among Malaysians $(n=1,290)$

\begin{tabular}{|c|c|c|c|c|}
\hline \multirow[b]{2}{*}{ Variables } & \multicolumn{4}{|c|}{ Frequency (\%) } \\
\hline & $\begin{array}{l}\text { Strongly } \\
\text { agree }\end{array}$ & Agree & Disagree & $\begin{array}{l}\text { Strongly } \\
\text { disagree }\end{array}$ \\
\hline $\begin{array}{l}\text { I am confident that I will not be infected with } \\
\text { coronavirus }\end{array}$ & $174(13.5)$ & $412(31.9)$ & $548(42.5)$ & $156(12.1)$ \\
\hline $\begin{array}{l}\text { I am confident that my body's immunity can fight } \\
\text { coronavirus infection }\end{array}$ & $125(9.7)$ & $493(38.2)$ & $566(43.9)$ & $106(8.2)$ \\
\hline $\begin{array}{l}\text { Controlling the spread of the COVID-19 pandemic is } \\
\text { my responsibility }\end{array}$ & $1,058(82.0)$ & $230(17.8)$ & $2(0.2)$ & $o(0)$ \\
\hline My behaviour can stop the transmission of COVID-19 & $970(75.2)$ & $313(24.3)$ & $6(0.5)$ & $1(0.1)$ \\
\hline $\begin{array}{l}\text { Government orders to stay at home can stop the } \\
\text { transmission of COVID-19 }\end{array}$ & $1,069(82.9)$ & $218(16.9)$ & $3(0.2)$ & $\mathrm{o}(\mathrm{o})$ \\
\hline $\begin{array}{l}\text { I will quarantine at home if I have flu symptoms like } \\
\text { fever, cough or runny nose }\end{array}$ & $926(71.8)$ & $286(22.2)$ & $61(4.7)$ & $17(1.3)$ \\
\hline $\begin{array}{l}\text { Wearing protective equipment like face masks and } \\
\text { gloves in public is simple for me }\end{array}$ & $668(51.8)$ & $548(42.5)$ & $71(5 \cdot 5)$ & $3(0.2)$ \\
\hline $\begin{array}{l}\text { Keeping one metre physical distant from other people } \\
\text { in public is simple for me }\end{array}$ & $715(55 \cdot 4)$ & 508 (39.4) & $65(5.0)$ & $2(0.2)$ \\
\hline
\end{tabular}


Original Article | Awareness, attitude and behaviour on COVID-19 transmission

Table 4. Compliant of Malaysians on the preventive behaviours against COVID-19 as recommended by the authorities

\begin{tabular}{lccc} 
& \multicolumn{3}{c}{ Frequency (\%) } \\
\cline { 2 - 4 } Preventive behaviour & All the time & Sometimes & Not at all \\
\hline I follow the order of authorities to stay at home & $1,119(86.7)$ & $171(13.3)$ & o (o) \\
I obey the prohibition to stay away from crowded places & $1,219(94.5)$ & $71(5.5)$ & o (o) \\
$\begin{array}{l}\text { I obey the prohibition against attending public gatherings } \\
\text { such as weddings, religious events, etc to prevent COVID-19 } \\
\text { infection }\end{array}$ & $1,287(99.8)$ & $3(0.2)$ & o (o) \\
$\begin{array}{l}\text { I avoid touching my eyes, nose or mouth to prevent COVID-19 } \\
\text { infection }\end{array}$ & $809(62.7)$ & $468(36.3)$ & $13(1.0)$ \\
$\begin{array}{l}\text { I wear a face mask in public places } \\
\text { I wear a face mask when I have the flu }\end{array}$ & $1,188(92.1)$ & $91(7.1)$ & $11(0.9)$ \\
$\begin{array}{l}\text { I cover my mouth with a tissue/handkerchief when sneezing or } \\
\text { coughing }\end{array}$ & $1,050(81.4)$ & $190(14.7)$ & $50(3.9)$ \\
$\begin{array}{l}\text { I wash my hands with soap after touching other people's } \\
\text { equipment or belongings }\end{array}$ & $1,098(85.1)$ & $189(14.7)$ & $3(0.2)$ \\
$\begin{array}{l}\text { I use hand sanitiser when in contact with any objects or } \\
\text { Surfaces that have an unknown hygienic state }\end{array}$ & $1,075(83.3)$ & $199(15.4)$ & $16(1.2)$ \\
$\begin{array}{l}\text { I maintain a distance of one metre from other people to } \\
\text { prevent COVID-19 infection }\end{array}$ & $1,195(92.6)$ & $95(7.4)$ & o (o)
\end{tabular}

Table 5. Distribution of total score of knowledge, attitude and preventive behaviour among Malaysians during COVID-19 pandemic

\begin{tabular}{lccc} 
& \multicolumn{2}{c}{ Percentage of total score } & Frequency of score \\
\cline { 2 - 3 } & Mean (SD) & Median (IQR) & $\begin{array}{c}\text { Mrove median (\%) } \\
\text { above }\end{array}$ \\
Knowledge and awareness & $88.9(11.2)$ & $88.9(11.1)$ & $612(47.4)$ \\
Susceptibility and intention attitude & $84.5(7.8)$ & $84.4(9.4)$ & $595(46.1)$ \\
Preventive behaviour & $92.4(9.1)$ & $95.0(10.0)$ & $516(40.0)$ \\
\hline
\end{tabular}

Next, we performed several simple logistic regressions to evaluate the association between sociodemographic characteristics and knowledge, attitude and preventive behaviour. Table 6 shows that there were significant associations between age and M40 income and poor knowledge. There were significant associations between age, sex, ethnicity, education level and M40 income and poor attitude, as shown in Table 7. There were significant associations between ethnicity, marital status and poor preventive behaviour and practices, as shown in Table 8.

The results by multiple logistic regression are displayed in Table 9. There was no interaction between variables. The selected models showed an overall fit, with the $P$-values of the Hosmer-Lemeshow test being nonsignificant. Age was significantly associated with knowledge when the occupation was adjusted
(AOR 0.98; 95\% CI: 0.97, 0.99; $P=0.026$ ). As the age increased by one year, there was a significant $2 \%$ reduction in the risk of poor knowledge. Sex and ethnicity were significantly associated with poor attitude. Males were 1.3-times more likely to have poor attitudes compared to females when age and ethnicity were adjusted for (AOR 1.35; 95\% CI: 1.05, 1.74; $P=0.021$ ). Malays had 1.4-times (AOR 1.41; 95\% CI: 1.01, 1.98; $P=0.043)$ and Chinese had 2.2-times (AOR 2.19; 95\% CI: 1.17, 4.13; $P=$ 0.015) the risk of poor attitude compared to other ethnicities when sex and age were adjusted for. Ethnicity was also significantly associated with behaviour with the Chinese people having a risk that was 2.8-times higher than that of other ethnicities with regard to poor behaviour when occupation was adjusted for (AOR 2.80; 95\% CI: 1.39, 5.61; $P=0.004)$. 
Table 6. Association between sociodemography characteristics and knowledge on COVID-19

\begin{tabular}{|c|c|c|c|c|}
\hline \multirow[b]{2}{*}{ Variables } & \multicolumn{2}{|c|}{ Frequency (\%) } & \multirow{2}{*}{$\begin{array}{l}\text { Crude OR } \\
(95 \% \text { CI })\end{array}$} & \multirow[b]{2}{*}{$P$-value* } \\
\hline & $\begin{array}{l}\text { Good level } \\
n=612\end{array}$ & $\begin{array}{c}\text { Poor level } \\
n=678\end{array}$ & & \\
\hline Age (years) & $43.12(10.10)^{\#}$ & $41.28(10.30)^{\#}$ & $0.98(0.97,0.99)$ & 0.001 \\
\hline \multicolumn{5}{|l|}{ Sex } \\
\hline Male & $159(26.0)$ & $175(25.8)$ & 1 & \\
\hline Female & $453(74.0)$ & $503(74.2)$ & $1.01(0.79,1.30)$ & 0.945 \\
\hline \multicolumn{5}{|l|}{ Ethnicity } \\
\hline Others & $68(11.1)$ & $93(13.7)$ & 1 & \\
\hline Malay & $500(81.7)$ & $553(81.6)$ & $0.81(0.58,1.13)$ & 0.215 \\
\hline Chinese & $31(5.1)$ & $25(3.7)$ & $0.59(0.32,1.09)$ & 0.091 \\
\hline Indian & $13(2.1)$ & $7(1.0)$ & $0.39(0.15,1.04)$ & 0.060 \\
\hline \multicolumn{5}{|l|}{ Marital status } \\
\hline Single & $96(15 \cdot 7)$ & $118(17.4)$ & 1 & \\
\hline Married & $486(79.4)$ & $527(77.7)$ & $0.88(0.66,1.19)$ & 0.407 \\
\hline Divorced/widow & $30(4.9)$ & $33(4.9)$ & $0.90(0.51,1.57)$ & 0.699 \\
\hline \multicolumn{5}{|l|}{ Education level } \\
\hline Primary school and less & $5(0.8)$ & $13(1.9)$ & 1 & \\
\hline High school & $66(10.8)$ & $80(11.8)$ & $0.47(0.16,1.38)$ & 0.167 \\
\hline Diploma & $110(18.0)$ & $117(17.3)$ & $0.41(0.14,1.19)$ & 0.100 \\
\hline Bachelor & $343(56.0)$ & $363(53.5)$ & $0.41(0.14,1.15)$ & 0.091 \\
\hline Master/PhD & $88(14.4)$ & $105(15.5)$ & $0.46(0.16,1.34)$ & 0.154 \\
\hline \multicolumn{5}{|l|}{ Occupation } \\
\hline Self-employed/odd job/others & $48(7.8)$ & $51(7 \cdot 5)$ & 1 & \\
\hline Government sector & $376(61.4)$ & $447(65.9)$ & $1.12(0.74,1.70)$ & 0.598 \\
\hline Private sector & $92(15.0)$ & $80(11.8)$ & $0.82(0.50,1.34)$ & 0.428 \\
\hline Housewife & $34(5.6)$ & $35(5.2)$ & $0.97(0.52,1.79)$ & 0.920 \\
\hline Retired/unemployed & $41(6.7)$ & $25(3.7)$ & $0.57(0.30,1.08)$ & 0.083 \\
\hline Student & $21(3.4)$ & $40(5 \cdot 9)$ & $1.79(0.93,3.46)$ & 0.763 \\
\hline \multicolumn{5}{|l|}{ Family income (RM) } \\
\hline $\mathrm{T} 20$ & $316(51.6)$ & $310(45 \cdot 7)$ & 1 & \\
\hline M40 & $177(28.9)$ & $208(30.7)$ & $1.37(1.03,1.82)$ & 0.030 \\
\hline $\mathrm{B} 40$ & $119(19.4)$ & $160(23.6)$ & $1.20(0.93,1.54)$ & 0.164 \\
\hline
\end{tabular}

Notes: *simple logistic regression; * mean (SD) 
Original Article | Awareness, attitude and behaviour on COVID-19 transmission

Table 7. Association between sociodemography characteristics and attitude on COVID-19

\begin{tabular}{|c|c|c|c|c|}
\hline \multirow[b]{2}{*}{ Variables } & \multicolumn{2}{|c|}{ Frequency (\%) } & \multirow{2}{*}{$\begin{array}{l}\text { Crude OR } \\
(95 \% \text { CI) }\end{array}$} & \multirow[b]{2}{*}{$P$-value* } \\
\hline & $\begin{array}{c}\text { Good level } \\
n=595\end{array}$ & $\begin{array}{c}\text { Poor level } \\
n=695\end{array}$ & & \\
\hline Age (years) & $41.51(10.00)^{\#}$ & $42.69(10.43)^{\#}$ & $1.01(1.00,1.02)$ & 0.039 \\
\hline \multicolumn{5}{|l|}{ Sex } \\
\hline Male & $137(23.0)$ & $197(28.3)$ & 1 & \\
\hline Female & $458(77.0)$ & $498(71.7)$ & $0.76(0.59,0.97)$ & 0.030 \\
\hline \multicolumn{5}{|l|}{ Ethnicity } \\
\hline Others & $88(14.8)$ & $73(10.5)$ & 1 & \\
\hline Malay & $479(80.5)$ & $574(82.6)$ & $1.45(1.04,2.02)$ & 0.030 \\
\hline Chinese & $20(3.4)$ & $36(5.2)$ & $2.17(1.16,4.07)$ & 0.016 \\
\hline Indian & $8(1.3)$ & $12(1.7)$ & $1.81(0.70,4.66)$ & 0.220 \\
\hline \multicolumn{5}{|l|}{ Marital status } \\
\hline Single & $106(17.8)$ & $108(15 \cdot 5)$ & 1 & \\
\hline Married & $460(77 \cdot 3)$ & $553(79.6)$ & $1.18(0.88,1.59)$ & 0.272 \\
\hline Divorced/widow & $29(4.9)$ & $34(4.9)$ & $1.15(0.65,2.02)$ & 0.625 \\
\hline \multicolumn{5}{|l|}{ Education level } \\
\hline Primary school and less & $2(0.3)$ & $16(2.3)$ & 1 & \\
\hline High school & $58(9.7)$ & $88(12.7)$ & $0.19(0.04,0.86)$ & 0.031 \\
\hline Diploma & $99(16.6)$ & $128(18.4)$ & $0.16(0.04,0.72)$ & 0.017 \\
\hline Bachelor & $343(57.6)$ & $363(52.2)$ & $0.13(0.03,0.58)$ & 0.007 \\
\hline Master/PhD & $93(15.6)$ & $100(14.4)$ & $0.13(0.03,0.60)$ & 0.009 \\
\hline \multicolumn{5}{|l|}{ Occupation } \\
\hline Self-employed/odd job/others & $43(7.2)$ & $56(8.1)$ & 1 & \\
\hline Government sector & $396(66.6)$ & $427(61.4)$ & $0.83(0.54,1.26)$ & 0.379 \\
\hline Private sector & $80(13.4)$ & $92(13.2)$ & $0.88(0.54,1.45)$ & 0.624 \\
\hline Housewife & $29(4.9)$ & $40(5.8)$ & $1.06(0.57,1.97)$ & 0.856 \\
\hline Retired/unemployed & $22(3.7)$ & $44(6.3)$ & $1.54(0.80,2.94)$ & 0.194 \\
\hline Student & $25(4.2)$ & $36(5.2)$ & $1.11(0.58,2.11)$ & 0.761 \\
\hline \multicolumn{5}{|l|}{ Family income (RM) } \\
\hline $\mathrm{T} 2 \mathrm{O}$ & $311(52.3)$ & $315(45 \cdot 3)$ & 1 & \\
\hline $\mathrm{M} 40$ & $172(28.9)$ & $213(30.6)$ & $1.47(1.11,1.96)$ & 0.008 \\
\hline $\mathrm{B} 40$ & $112(18.8)$ & $167(24.0)$ & $1.22(0.95,1.58)$ & 0.122 \\
\hline
\end{tabular}

Notes: *simple logistic regression; ${ }^{*}$ mean (SD) 
Table 8. Association between sociodemography characteristics and preventive behaviour, and practices on COVID-19

\begin{tabular}{|c|c|c|c|c|}
\hline \multirow[b]{2}{*}{ Variables } & \multicolumn{2}{|c|}{ Frequency (\%) } & \multirow{2}{*}{$\begin{array}{c}\text { Crude OR } \\
(95 \% \text { CI) }\end{array}$} & \multirow[b]{2}{*}{ P-value } \\
\hline & $\begin{array}{c}\text { Good level } \\
n=516\end{array}$ & $\begin{array}{c}\text { Poor level } \\
n=774\end{array}$ & & \\
\hline Age (years) & $42.82(9.48)^{\#}$ & $41.71(10.55)^{\#}$ & $0.99(0.98,1.00)$ & 0.057 \\
\hline \multicolumn{5}{|l|}{ Sex } \\
\hline Male & $127(24.6)$ & $207(26.7)$ & 1 & \\
\hline Female & $389(75.4)$ & $567(73 \cdot 3)$ & $0.89(0.69,1.16)$ & 0.392 \\
\hline \multicolumn{5}{|l|}{ Ethnicity } \\
\hline Others & $78(15.1)$ & $83(10.7)$ & 1 & \\
\hline Malay & $415(80.4)$ & $638(82.4)$ & $1.45(1.04,2.02)$ & 0.030 \\
\hline Chinese & $13(2.5)$ & $43(5.6)$ & $3.11(1.55,6.22)$ & 0.001 \\
\hline Indian & $10(1.9)$ & $10(1.3)$ & $0.94(0.37,2.38)$ & 0.940 \\
\hline \multicolumn{5}{|l|}{ Marital status } \\
\hline Single & $63(12.2)$ & $151(19.5)$ & 1 & \\
\hline Married & $430(83.3)$ & $583(75 \cdot 3)$ & $0.57(0.41,0.78)$ & $<0.001$ \\
\hline Divorced/widow & $23(4.5)$ & $40(5.2)$ & $0.73(0.40,1.31)$ & 0.288 \\
\hline \multicolumn{5}{|l|}{ Education level } \\
\hline Primary school and less & $8(1.6)$ & $10(1.3)$ & 1 & \\
\hline High school & $53(10.3)$ & $93(12.0)$ & $1.40(0.52,3.77)$ & 0.501 \\
\hline Diploma & $91(17.6)$ & $136(17.6)$ & $1.20(0.45,3.14)$ & 0.717 \\
\hline Bachelor & $301(58.3)$ & $405(52.3)$ & $1.08(0.42,2.76)$ & 0.878 \\
\hline Master/PhD & $63(12.2)$ & $130(16.8)$ & $1.65(0.62,4.39)$ & 0.315 \\
\hline \multicolumn{5}{|l|}{ Occupation } \\
\hline Self-employed/odd job/others & $33(6.4)$ & $66(8.5)$ & 1 & \\
\hline Government sector & $365(70.7)$ & $458(59.2)$ & $0.63(0.40,0.97)$ & 0.038 \\
\hline Private sector & $60(11.6)$ & $112(14.5)$ & $0.93(0.55,1.57)$ & 0.796 \\
\hline Housewife & $20(3.9)$ & $49(6.3)$ & $1.23(0.63,2.39)$ & 0.551 \\
\hline Retired/unemployed & $25(4.8)$ & $41(5 \cdot 3)$ & $0.82(0.43,1.57)$ & 0.549 \\
\hline Student & $13(2.5)$ & $48(6.2)$ & $1.85(0.88,3.88)$ & 0.105 \\
\hline \multicolumn{5}{|l|}{ Family income (RM) } \\
\hline T2O & $260(50.4)$ & $366(47 \cdot 3)$ & 1 & \\
\hline M40 & $153(29.7)$ & $232(30.0)$ & $1.21(0.91,1.62)$ & 0.191 \\
\hline $\mathrm{B} 40$ & $103(20.0)$ & $176(22.7)$ & $1.08(0.83,1.40)$ & 0.573 \\
\hline
\end{tabular}

Notes: *simple logistic regression; *mean (SD) 
Original Article | Awareness, attitude and behaviour on COVID-19 transmission

Table 9. Association between sociodemography characteristics and poor of knowledge, attitude and behaviour on COVID-19

\begin{tabular}{|c|c|c|c|}
\hline \multirow{2}{*}{ Variables } & \multicolumn{3}{|c|}{$\operatorname{AOR}(95 \% \mathrm{CI})^{*}$} \\
\hline & Knowledge & Attitude & Behaviour \\
\hline \multicolumn{4}{|l|}{ Model summary } \\
\hline \multicolumn{4}{|l|}{ Hosmer-Lemeshow test } \\
\hline Age (years) & $0.98(0.97,0.99)^{*}$ & $1.01(1.00,1.02)^{*}$ & \\
\hline \multicolumn{4}{|l|}{ Sex } \\
\hline Female & & 1 & \\
\hline Male & & $1.35(1.05,1.74)^{*}$ & \\
\hline \multicolumn{4}{|l|}{ Ethnicity } \\
\hline Others & & 1 & 1 \\
\hline Malay & & $1.41(1.01,1.98)^{*}$ & $1.28(0.91,1.80)$ \\
\hline Chinese & & $2.19(1.19,4.13)^{*}$ & $2.80(1.39,5.61)^{*}$ \\
\hline Indian & & $1.77(0.68,4.58)$ & $0.92(0.36,2.34)$ \\
\hline \multicolumn{4}{|l|}{ Occupation } \\
\hline Self-employed/odd job/others & 1 & & 1 \\
\hline Government sector & $1.14(0.75,1.74)$ & & $0.64(0.41,1.00)$ \\
\hline Private sector & $0.78(0.47,1.28)$ & & $0.94(0.56,1.58)$ \\
\hline Housewife & $0.96(0.52,1.78)$ & & $1.24(0.64,2.42)$ \\
\hline Retired/unemployed & $0.72(0.37,1.41)$ & & $0.82(0.43,1.57)$ \\
\hline Student & $1.35(0.67,2.73)$ & & $1.77(0.84,3.73)$ \\
\hline
\end{tabular}

Notes: ${ }^{*} P<0.05$; \#multiple logistic regression; assumptions of linearity, multicollinearity and interaction were checked and found none

\section{Discussion}

Most of our participants had higher education, were employed and were from the top $20 \%$ of household incomes. These characteristics corresponded to people who had access to the internet and smartphones. Smartphone users in Malaysia increased from $75.9 \%$ in 2017 to $78.0 \%$ in 2018 (10). Smartphone users who access the internet through their smartphones are growing at an average annual growth rate of $5.45 \%$. In 2018, 94.6\% of smartphone users were using their phones to go online. This provides an excellent opportunity to educate people through electronic media and social networks such as WhatsApp, Twitter and Facebook.

Most of our participants were aware of and knowledgeable about COVID-19. This indicated that the participants actively read the news and policies from the government. Among the knowledge statements, only $77.0 \%$ agreed on the eyes as a portal of entry, while only $57.3 \%$ and $60.1 \%$ agreed on lethargy and runny nose as symptoms of COVID-19, respectively. These are the aspects that need emphasis in COVID-19 education for the public.

Most participants were aware of the mode of transmission of the virus, as more than $90 \%$ answered yes for all of the statements. The main mode of transmission of COVID-19 is direct person to person contact and through respiratory droplets when someone speaks, coughs or sneezes $(11,12)$. It can also be transmitted when people are in close contact of one metre with each other. The droplets can then be inhaled, or can land on surfaces, which others may come into contact with, and who can then be infected by touching their nose, mouth or eyes. The virus can survive on inanimate surfaces like metal, glass or plastics from several hours to a few days, thus providing a source of continuous 
transmission if they were not cleaned regularly (13).

Only $58.7 \%$ agreed that the COVID-19 virus is transmissible through the consumption of wild animals. This is a controversial issue. There is a zoonotic linkage with SARS-CoV-2 and animals such as bats, civets and pangolins $(1,2,14)$. It was concluded that there was no scientific evidence to support the animalhuman connection, although there was a strong suspicion.

There are several symptoms and complications caused by the virus, including fever, headache, cough, tiredness, dyspnoea, myalgia and anosmia, with some individuals developing acute respiratory distress syndrome about a week after the onset of the disease, which can lead to death (1). There is evidence suggesting that transmission can be caused by asymptomatic carriers (15). Most of our respondents were aware of this fact, therefore they were cautious of viral exposure when meeting people unknown to them. Nasopharyngeal swabs were obtained from 210 pregnant women admitted for delivery in New York who were asymptomatic for COVID-19, with $13.7 \%$ found to be positive for SARS-CoV-2 (16). A screening in Iceland reported $13.3 \%$ positive results for SARS-CoV-2 among persons at high risk for infection such as symptomatic individuals, and those who had recently travelled to high-risk countries or had been in contact with infected persons. In contrast, $0.8 \%$ positive results were reported among the general population from open-invitation screening and $0.6 \%$ in the random-population screening (17).

A positive attitude can improve the outcomes of COVID-19, which includes feeling vulnerable and having the intention and motivation to comply with the rules and regulation to prevent the transmission of COVID-19. The Health Belief Model states that individuals who feel vulnerable to a particular health problem will adopt behaviours to reduce their risk of developing the health problem (18). More than half of our respondents disagreed with the attitude statements concerning the vulnerability of them to infection. On the other hand, most of our respondents agreed with statements regarding other intentions of complying with preventive behaviours.

The World Health Organization recommends important practices to reduce the risk of COVID-19 infection by washing hands frequently with soap and water, or by using an alcohol-based hand sanitiser, along with respiratory hygiene, maintaining the social distance of one metre and avoiding touching the eyes, nose and mouth $(4,7)$. The Ministry of Health Malaysia also recommends the use of face masks, which can prevent or reduce transmission if worn properly. The compliance of preventive behaviours, such as staying at home and avoiding crowded places was respected all the time by our respondents. Avoiding touching the face and covering the mouth with a tissue or handkerchief when sneezing or coughing were only sometimes complied with. Wearing face masks when having the flu was not practiced at all for some respondents. Wearing a face mask when having a flu whose status is unknown is a strategy to reduce public exposure to a possible COVID-19.

Older participants were significantly associated with poor knowledge. This is probably consistent with the fact that older people were less likely to engage with news posted in social media compared to younger people. In terms of attitude, males were more likely to have a poor attitude. Surprisingly, Malay and Chinese had a poor attitude compared to other ethnics in Malaysia. Other ethnics referred to ethnics in Sabah and Sarawak. The Chinese were at higher risk than other ethnicities for poor behaviour. There was no similar study found to compare with our results. However, a study on hepatitis reported that females and those with a doctorate education generally have better knowledge than the comparison group. Meanwhile, older age and married status were significantly associated with a better attitude and older age, being married and being females were significantly associated with good practices (19). In contrast, it was reported that older people, and those with a higher education and low self-perceived risk were more likely to have a positive attitude towards cancer information (20).

This study had large and representative samples of participants from all states in Malaysia. This study used an online method that is free from interviewer bias. A multivariable analysis was used to control the study confounders. However, there were several limitations of this study. Although our respondents were representative of all Malaysian states, our results showed that most of our respondents were in high education and income groups. For these reasons, our results showed a high level of knowledge, attitudes and practices. We used previously validated questionnaires of the $\mathrm{H} 1 \mathrm{~N} 1$ epidemic with some modifications. 
Original Article | Awareness, attitude and behaviour on COVID-19 transmission

Since we wanted to conduct this study during the peak of the pandemic, we did not revalidate the questionnaires.

\section{Conclusion}

The level of knowledge and awareness, attitude and practices was high except for a few questions. When we categorised them by median score, $40.0 \%, 46.1 \%$ and $47.4 \%$ of participants had poor scores for knowledge and awareness, attitude and practices, respectively. Young individuals, males, and Malay and Chinese ethnics need health education to increase their knowledge, attitudes and behaviours toward the prevention of COVID-19 in Malaysia.

Each individual in Malaysia plays an important role in breaking the transmission of COVID-19. We strongly support awareness and health promotion strategies as an integral part of a COVID-19 prevention and control programme.

\section{Acknowledgements}

We would like to thank Ms Haiyu for her involvement in the study.

\section{Ethics of Study}

This study was conducted in strict adherence to ethical considerations, with ethical approval obtained from the Human Research Ethics Committee Universiti Sains Malaysia [USM/JEPeM/COVID19-27]. There is no identification of the response to any individual. We ensured the privacy and confidentiality of participants.

\section{Conflict of Interest}

None.

\section{Funds}

None.

\section{Authors' Contributions}

Conception and design: NB, AKG, RH

Analysis and interpretation of the data: NB

Drafting of the article: NB

Critical revision of the article for important

intellectual content: $\mathrm{NB}, \mathrm{AKG}, \mathrm{RH}$

Final approval of the article: NB, AKG, RH

Provision of study materials or patients: NB

Statistical expertise: NB

Administrative, technical or logistic support: NB, AKG, RH

Collection and assembly of data: NB

\section{Correspondence}

Professor Dr Bachok Norsa'adah

MBBS (Flinders), MComMed (USM), PhD

(UKM)

Unit of Biostatistics and Research Methodology,

School of Medical Sciences,

Universiti Sains Malaysia,

16150 Kubang Kerian, Kelantan, Malaysia.

Tel: +609 7676827

Fax: +609 7653370

E-mail: norsaadah@usm.my

\section{References}

1. Yi Y, Lagniton PNP, Ye S, Li E, Xu R-H. Review COVID-19: what has been learned and to be learned about the novel coronavirus disease. Int $J$ Biol Sci. 2020;16(10):1753-1766. https://doi. org/10.7150/ijbs.45134

2. Shereen MA, Khan S, Kazmi A. COVID-19 infection: origin, transmission and characteristics of human coronaviruses. J Adv Res. 2020;24:9198.

3. Wikimedia Foundation Inc. COVID-19 pandemic in Malaysia. 2020. [Retrieved 2020 Oct 31] Available at: https://en.wikipedia.org/wiki/ COVID-19_pandemic_in_Malaysia

4. World Health Organization. Coronavirus disease (COVID-19) pandemic [Internet]; 2020. [Retrieved 2020 May 20]. Available at: http:// www.euro.who.int/en/health-topics/healthemergencies/coronavirus-covid-19/novelcoronavirus-2019-ncov 
5. Ministry of Health Malaysia. Situasi semasa pandemik COVID-19 di Malaysia; 2020. [Retrieved 2020 May 20]. Available at: http:// covid-19.moh.gov.my/

6. Department of Statistics Malaysia. Population distribution and basic demographic characteristic report 2010 [Internet]; 2020. (updated 2015 May 7). [Retrieved 2020 May 20]. Available at: https://www.dosm.gov.my/v1/index.php? $\mathrm{r}=$ column/ctheme\&menu_id=LopheU43N WJwRWVSZklWdzQ4TlhUUTOo9\&bul_id= MDMxdHZjWTk1SjFzTzNkRXYzcVZjdzo9 \#: :text=Population\%2odistribution\%20 by\%20state\%2oindicated,Putrajaya\%20(72\%2 C413)\%20and\%20W\%20

7. Parvin F, Islam S, Urmy Z, Ahmed S. The symptoms, contagious process, prevention and post-treatment of COVID-19. Eur $J$ Physiother Rehab Stu. 2020;1(1):81-105.

8. Nadiah W-A, Norsa'adah B, Naing NN, Zaliha Il, Azriani AR, Nik-Rosmawati NH, Mohamed-Rusli A. Knowledge, attitude and practices on influenza A (H1N1) among Kelantanese school children. Southeast Asian J Trop Med Public Health. 2012;43(6):1-13.

9. Department of Statistics Malaysia. 2017. Report of household income and basic amenities survey 2016 [Internet]. [Retrieved 2020 May 20]. Available at: https://www.dosm.gov.my/v1/index. php?r=column/pdfPrev\&id=RUZ5REwveU1ra1h GL21JWVlPRmU2Zzo9

10. Malaysian Communications and Multimedia Commission. Hand phone users survey 2018 [Internet]. [Retrieved 2020 May 20]. Available at: https://www.mcmc.gov.my/skmmgovmy/media/ General/pdf/HPUS2018.pdf

11. Lai C-C, Shih T-P, Ko W-C, Tang H-J, Hsueh P-R. Severe acute respiratory syndrome coronavirus 2 (SARS-CoV-2) and coronavirus disease-2019 (COVID-19): the epidemic and the challenges. Int $J$ Antimicrob Agents. 2020;55:105924. https:// doi.org/10.1016/j.ijantimicag.2020.105924

12. Buxton G. Spreadsheet model of COVID-19 transmission: evaporation and dispersion of respiratory droplets. SSRN. 2020;12(2):1-20. Available at: https://ssrn.com/abstract $=3582665$ or http://dx.doi.org/10.2139/ssrn.3582665
13. Kampf G, Todt D, Pfaender S, Steinmann E. Persistence of coronaviruses on inanimate surfaces and its inactivation with biocidal agents. $J$ Hosp Infect. 2020;104(3):246-251. https:// doi.org/10.1016/j.jhin.2020.01.022

14. Tiwari R, Dhama K, Sharun K, Yatoo MI, Malik YS, Singh R, et al. COVID-19: animals, veterinary and zoonotic links. Vet Q. 2020;40(1):169-182. https://doi.org/10.1080/01652176.2020.1766725

15. Bai Y, Yao L, Wei T, Tian F, Jin D-Y, Chen $\mathrm{L}$, et al. Presumed asymptomatic carrier transmission of COVID-19. J Ame Med Assoc. 2020;323(14):1406-1407.

16. Sutton D, Fuchs K, D'Alton M, Goffman D. Universal screening for SARS-CoV-2 in women admitted for delivery. New Engl $J$ Med. 2020;382:2163-2164. https://doi.org/10.1056/ NEJMc2009316

17. Gudbjartsson DF, Helgason A, Jonsson $\mathrm{H}$, et al. Spread of SARS-CoV-2 in the Icelandic population. New Engl $J$ Med. 2020;382(24):2302-2315. https://doi. org/10.1056/NEJMoa2006100

18. Glanz K, Rimer BK, Viswanath K. Health behavior and health education: theory, research and practice. 4th ed. San Francisco: Jossey-Bass; 2008.

19. Ahmad A, Sann LM, Rahman HA. Factors associated with knowledge, attitude and practice related to hepatitis $\mathrm{B}$ and $\mathrm{C}$ among International students of Universiti Putra Malaysia. BMC Public Health. 2016;16:611. https://doi.org/10.1186/ s12889-016-3188-5

20. Sanz-Barbero B, Prieto M, Cambas N. Factors associated with a positive attitude towards receiving cancer information: a population-based study in Spain. Health Expect. 2015;19(2):288298. https://doi.org/10.1111/hex.12349 